\title{
THE IMPACT OF CONTAINER TYPE DIVERSIFICATION ON REGIONAL BRITISH PORT DEVELOPMENT STRATEGIES
}

This is the pre-published version of the text. The final published paper can be found at:

Monios, J., Wilmsmeier, G. (2014). The impact of container type diversification on regional British port development strategies. Transport Reviews. 34 (5): 583-606.

DOI: $10.1080 / 01441647.2014 .946457$

\begin{abstract}
Despite a concentration of container traffic in the southeast of the UK over the last few decades, regional ports are attempting new development strategies to capture or retain specific traffic segments. These include intra-European short sea traffic and a potentially increasing feeder market. These trends are reflected in the movement of different container types, which result in a number of planning challenges related to changing infrastructural and operational requirements.
\end{abstract}

This paper uses highly disaggregated data on container type movements to address three issues that can inform these planning challenges. First, the imbalance of trade resulting in empty container repositioning; second, the requirement for gauge-cleared rail routes to cater for the increasing proportion of high-cube containers; and third, the specialisation of European short sea traffic at secondary UK ports. Results reveal the disproportionate repositioning of empty containers at Scottish ports and the importance of $45 \mathrm{ft}$, high-cube and pallet-wide containers at regional ports, highlighting their focus on intra-European short sea traffic and raising difficulties relating to their lower quality of landside infrastructure (particularly rail) in comparison to the large south-eastern ports. The potential repercussions on hinterland infrastructure development raise questions about both public and private sector responses to regional port development.

Keywords: container ports, shipping, rail, intermodal, infrastructure, policy, port-centric logistics, regional, hinterland, integration 


\section{Introduction}

Over the last three decades the UK container port system experienced a concentration of traffic in the southeast of the country. The main container ports are now located close to the English Channel, and secondary ports are attempting new development strategies to retain or capture traffic segments such as intra-European short sea and a potentially increasing feeder market. Regional ports now seek to reposition themselves within the market in a particular way, based to a large degree on the concept of port-centric logistics, aiming to anchor traffic at ports through the availability of cheap industrial land for the location of distribution facilities.

These emerging trends of specialisation drive new requirements for infrastructure and operations, reflected in the movement of different container types. The question arising is whether changes in logistics strategies and lack of infrastructure development are influencing the evolution of the British port system. Answering this question can help private and public sector actors direct future infrastructure investment. Existing studies on port system evolution usually do not take geographical or container type specialisation into account, but container type specialisation is becoming more relevant as container types diversify.

Transport infrastructure is upgraded piecemeal in reaction to developments in the freight and passenger sectors. Heavier lorries require stronger roads, capacity constraints on rail are addressed through the provision of additional tracks, passing loops and loading gauge clearances, while ports wanting to serve increasingly large container vessels need deeper access channels and longer berths as well as improved landside links. While infrastructure is for the most part a public responsibility, cost sharing for upgrading links to privately-owned and -operated ports can be a contentious matter. In order for public sector planners to negotiate this process with more certainty, they require greater detail on container movements and their operational requirements; however, the commercial nature of the maritime sector means that these data are not always readily available. The goal of this paper is to inform planners, both public and private, who seek to ensure investment is targeted where it is required. This goal is achieved through analysis of a new dataset, previously unpublished in the literature.

A large literature has developed in recent years charting the ways in which large ports have sought greater integration with their hinterlands, yet regional ports remain underresearched. Even a small shift in traffic to another port may undermine the viability of a regional port, as well as limit any potential for competitive strategies of expansion. Yet, such ports do not have the same level of available resources and institutional capacity as larger 
ports and must therefore focus on their specific regional advantages. As regional ports are more embedded in their local trades, they need to tie their development plans (especially port-centric logistics hopes) to the specific transport and logistics requirements of the port users.

In their analysis of the UK container port system, Wilmsmeier \& Monios (2013) identified a need for further research into imbalances of container flows, the impact on hinterland infrastructure development and the dynamics of container type diversification in order to understand the intersection between port development and logistics strategies. This paper will address that research agenda by analysing container movements by type and dimension at UK ports, examining the role of empty repositioning and the movement of $45 \mathrm{ft}$, high-cube ${ }^{1}$ and pallet-wide ${ }^{2}$ containers. The infrastructural focus of this paper is primarily on rail, set against a policy background over the last decade in which modal shift from road to rail has been encouraged by governments as one way to reduce carbon emissions (DETR, 1998; European Commission, 2001), but balancing inbound and outbound container flows also affects road haulage.

As major ports across Europe continue to expand, regional ports are seeking a new role. This paper will use the British case to explore how logistical requirements can influence a port's development plans. The analysis addresses three issues that can inform the planning challenges arising from the preceding discussion. The role of empty repositioning, due to the trade imbalance in the UK, results in increased transport costs for British shippers. The paper will analyse empty movements by port to obtain further insight into this question. Second, as high-cube movements increase but the UK rail network is not all gauge-cleared to allow their movement, this paper will analyse high-cube movements by port. Third, the paper will analyse movement of short sea $45 \mathrm{ft}$ pallet-wide containers to consider the role of specialisation of European trade at regional UK ports.

Section two reviews the literature on port hinterland integration to demonstrate how many ports across Europe are seeking greater collaboration with inland actors to address the logistical requirements that underpin their demand for container handling at the port. Section three provides an overview of UK port geography and identifies key issues from previous research, while section four provides more context on the role of container types in UK trade and derives the three research topics. Section five discusses the use of data in this analysis.

\footnotetext{
${ }^{1}$ High-cube containers are $9 \mathrm{ft} 6$ high, compared to the standard height of $8 \mathrm{ft} 6$ - see section four.

${ }^{2}$ These are 2.4 inches wider than standard containers in order to fit more pallets in - see section four.
} 
Results are presented in section six, before discussion in section seven, concluding with the relevance of these findings for regional ports in the UK as well as across Europe.

\section{Literature review}

A large literature has developed in recent years analysing the various ways in which ports are becoming increasingly integrated with their hinterlands (e.g. Notteboom \& Rodrigue, 2005; de Langen, 2008; Rodrigue \& Notteboom, 2010; Monios \& Wilmsmeier, 2013). Analyses of such hinterland integration can be divided into two approaches: organisational and operational.

The first stream of literature addresses the organisational and institutional aspects of port hinterland integration. What these papers reveal is that ports across Europe are increasingly attempting to secure their hinterlands by cooperating with inland actors, for example to develop inland terminals (Bergqvist, 2008; Notteboom \& Rodrigue, 2009; Roso et al., 2009; Rodrigue et al., 2010; Ng \& Cetin, 2012; Monios \& Wilmsmeier, 2012a) and increase the efficiency of transport services (Ducruet \& Van der Horst, 2009; Woxenius \& Bergqvist, 2011; Van den Berg et al., 2012; De Langen \& Sharypova, 2013). However, these kinds of direct actions in the hinterland tend to be the province of larger ports with the available resources and significant institutional capacity. Smaller regional ports are rarely in a position to do so and must focus on their advantages which often include available brownfield land, cheaper rents in the vicinity and a large pool of semi-skilled labour.

Port development and its impact on the hinterland can give rise to complex planning issues for both private freight operators and public planners seeking to influence the location of logistics facilities (Caris et al., 2008; Hesse \& Rodrigue, 2004; Flämig \& Hesse, 2011). These planning challenges are even more important for regional ports; unlike deep sea ports that compete for large overlapping hinterlands and thus focus predominantly on volume, regional ports must serve the specific needs of local shippers (Cahoon et al., 2012). They must therefore synchronise their port development strategies with the industry requirements that drive container flows in their region. However, available data on equipment requirements and usage that can aid port planners are difficult to acquire due to commercial sensitivity. The result is that inputs into port planning are to a large degree provided by economic models of trade flows, as represented by the second stream of literature, dealing with the operational side of port hinterland integration.

This second stream of literature assesses the role of transport actors in choosing intermodal transport (Van Schijndel and Dinwoodie, 2000; Panayides, 2002; Bärthel \& 
Woxenius, 2004; Runhaar \& van der Heijden, 2005), the economic feasibility of rail shuttles (Ballis \& Golias, 2002; Arnold et al., 2004; Janic, 2007; Kreutzberger, 2008; Kim \& Wee, 2011; Iannone, 2012) and the importance of aligning cargo types with intermodal service characteristics (Woodburn, 2003; Slack \& Vogt, 2007; Van der Horst \& de Langen, 2008; Woodburn, 2011; Eng-Larsson \& Kohn, 2012). The literature reveals that the use of rail transport at European ports remains challenged by fragmented demand and short distances. Even in cases where flows can be concentrated on regular shuttles, economic feasibility can be threatened by an inability to match equipment and demand in both directions. Woodburn (2011) showed how modelling analyses can be strengthened by using empirical data on load factors and train lengths rather than assumptions. This paper uses empirical data on container

types to identify potential causes of inefficiency that will limit the ability of rail operators to run regular full shuttles, in addition to the balancing of pre- and end-haul road transport movements.

\section{UK port geography}

Ocean shipping costs have reduced drastically over recent decades due to the adoption of containerisation and the increased economies of scale available from ever-increasing ship size (Cullinane \& Khanna, 1999). Shipping services were rationalised, with large vessels traversing major routes between a limited number of hub ports. Cargo was then sent inland or feedered to smaller ports. In the UK, the result was that over the last 30 years trade flows shifted from choosing the nearest local port to using the large south-eastern ports (Hoare, 1986; Overman \& Winters, 2005; Pettit \& Beresford, 2008; Asteris \& Collins, 2010).

Figure 1 shows the container throughput rankings of the top 15 UK ports over the last decade. 


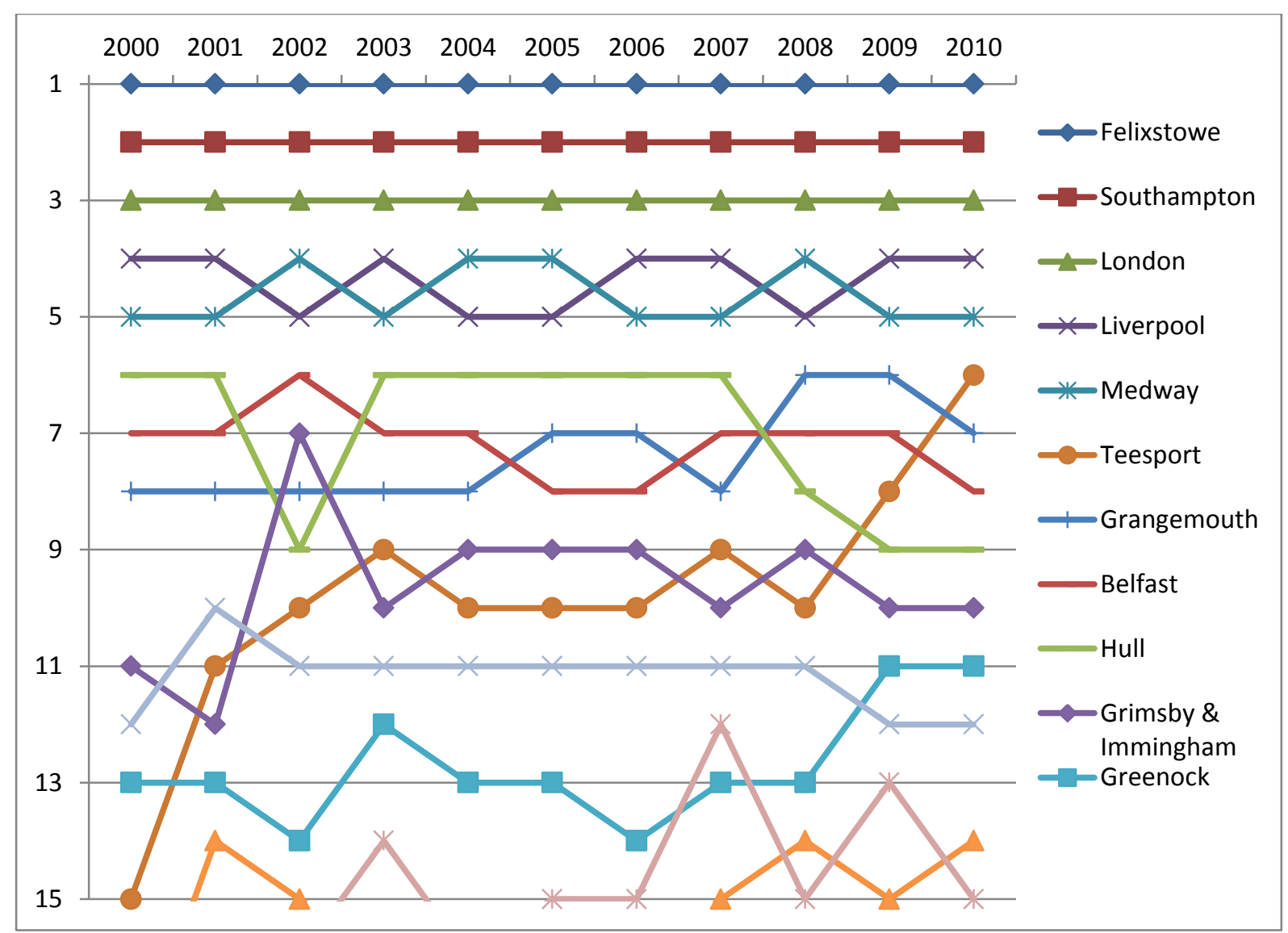

Figure 1. UK ports ranked by container throughput, 2000-2010

Source: authors, based on DfT, 2011

The figure shows that the top five ports remain static, but significant movement can be observed among secondary ports. The success of Teesport is particularly clear, especially as it has improved its ranking during a recession.

Figure 2 depicts regional specialisation in the UK port system. 


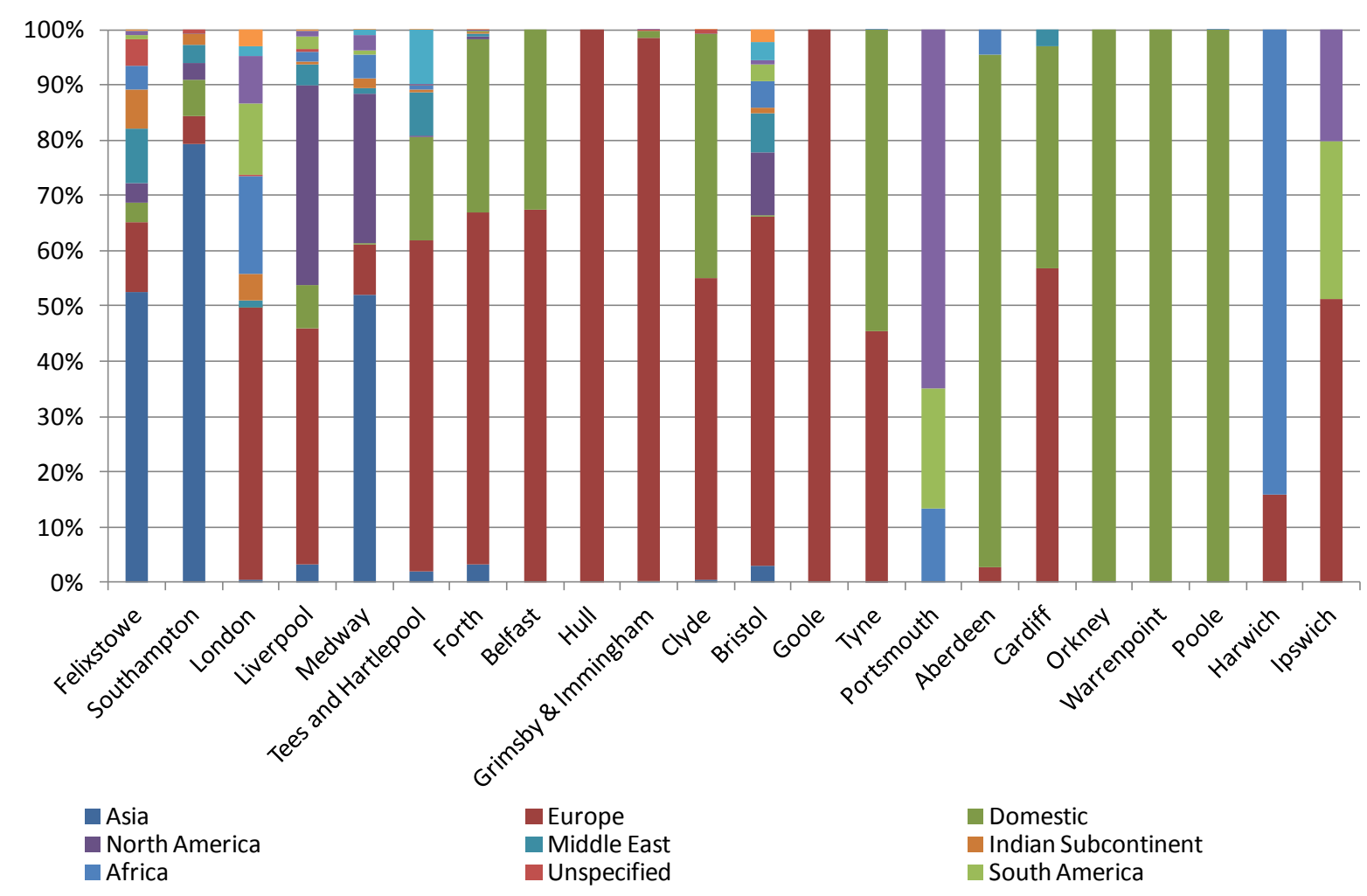

Figure 2. Regional specialisation in the UK port system, 2010

Source: Wilmsmeier \& Monios, 2013

The figure shows that the deep sea Asian routes are concentrated in three UK ports (Felixstowe, Southampton and Medway Thamesport). Liverpool's west coast location means that it focuses on North American and Irish trade. London Tilbury specialises in intraEuropean cargo, with over $50 \%$ of its throughput originating in or destined for Europe, with the rest split between other global regions. Of particular interest is that, at the secondary ports too small for direct deep sea links, European traffic outweighs domestic container traffic, reaching over $50 \%$ of all traffic in these ports.

Many UK ports have recently completed or are planning major developments. The expansion of Felixstowe is complete as is the entirely new terminal at London Gateway. Southampton's proposal for a development at Dibden Bay failed in the planning process but the port is planning development within its existing footprint. In the past, UK ports were considered to be short of capacity, one possible reason for the decline in the UK range's share of European traffic, from over 15\% in 1996 to around 9\% in 2008 (Notteboom, 2010). The danger now is quite the opposite.

Besides these developments at the dominant deep sea ports, major port developments have also been approved at Liverpool, Teesport and Bristol. Liverpool is currently the fourth 
busiest container port in the UK, receiving deep sea calls from across the Atlantic, but hoping eventually to attract Asian links. Its 2010 throughput was 657,264 TEU, and the development of a new container terminal is being pursued that would add approximately 500,000 TEU capacity to the current limit of around $1 \mathrm{~m}$ TEU. Teesport had already upgraded the container terminal in 2003 to a nominal stated capacity of 235,000 TEU; this has now been exceeded as the port handled 247,132 TEU in 2010. Expansion is planned in stages, with the eventual aim of $1.5 \mathrm{~m}$ TEU. As the port can handle vessels up to 3,500 TEU, it could accommodate some feeder vessels that may cascade down once larger vessels enter service on the mainlines, making it well-placed to compete for UK feeder cargo, particularly in the north. Compared to these ports, Bristol is currently a small container port $(68,673$ TEU in 2010$)$, yet $£ 600 \mathrm{~m}$ is being invested in a new deep-sea container terminal with a capacity of $1.5 \mathrm{~m}$ TEU. In Scotland, a new container terminal has been proposed for the port of Rosyth, aiming initially for capacity of 450,000 TEU, and future expansion to 600,000 TEU. Such developments suggest that these regional ports expect increased traffic in the coming years.

Most proposed developments at regional ports attempt to distinguish themselves from deep sea ports via a market offer of port-centric logistics, hoping to anchor tenants at the port through the provision of logistics facilities (Mangan et al., 2008; Pettit \& Beresford, 2009; Monios \& Wilmsmeier, 2012b). In distinction to deep sea ports in the southeast, regional ports can generally offer uncongested handling facilities and cheap brownfield land for development; however, their landside links (particularly expensive rail infrastructure) tend to be of lower quality than large ports. The current centralised UK inland distribution network was developed when industrial and retail inputs were primarily UK-sourced; the processing of imports arriving at coastal ports may act as a driver to decentralise operations, but this will only be attractive to some customers. If cheaper land and labour and supportive regional development policies are insufficient, an increasing density of container flows at regional ports may provide the economies of scale to increase the feasibility of distribution from such locations.

\section{The role of container types in UK trade}

The vast majority of ISO containers used on deep sea trades are 20ft and 40ft long, mostly $8 \mathrm{ft}$ wide, and either $8 \mathrm{ft} 6$ high (standard height) or, increasingly, $9 \mathrm{ft} 6$ high (known as "high-cube"). Intra-European shipments move in $45 \mathrm{ft}$ containers, likewise with a standard width of $8 \mathrm{ft}$ and available in both standard height and high cube. In recent years, "palletwide" containers have been developed on European short sea routes. These are 2.4 inches 
wider than standard containers, giving the same internal width as a road trailer $(2.44 \mathrm{~m})$, and thus able to fit the same number of pallets. ${ }^{3}$ There is a move in Europe to make $45 \mathrm{ft}$ palletwide maritime containers the industry standard (Bouley, 2012). The problem with this proposal is that most deep-sea ships cannot accommodate these containers in their 20/40ft cellular holds and EU directive 96/53/EC forbids standard 45ft long containers on lorries (although modified designs with chamfered corners are acceptable).

Large retailers as the key drivers of intermodal transport in the UK were studied in detail by Monios (2012). Most domestic intermodal containers used by third-party logistics providers (3PLs) such as Eddie Stobart, WH Malcolm and JG Russell are 45ft pallet-wide to deal with the issues noted above. However their design differs across companies. The Stobart/Tesco containers are curtain siders, which is common on lorries but not on trains. As trains are often required to stop on the line during the night, they can be targets for pilferage, therefore generally rigid boxes are preferred (though not immune themselves). Similarly, curtain siders, like swap bodies, cannot be stacked as standard ISO maritime boxes can. Another difference between road trailers and rail containers is that $\mathrm{HGVs}$ can be compartmentalised for chilled, frozen or ambient but current rail containers cannot, which limits their flexibility. All of these operational issues contribute to the decision to use rail (or not). Additionally, domestic 45ft containers are generally standard height to avoid issues with loading gauge on the UK network, which is not all cleared to accept high-cube containers on standard wagons (of which more below).

Direct container train services from UK ports to the Midlands have grown over the last decade while direct services from UK ports to Scotland have fallen (Woodburn, 2007). This may be explained by the integration of Scottish trade flows into a centralised UK distribution network concentrated in the Midlands and to a lesser extent Yorkshire and Lancashire. Competitive coastal feeder services from Felixstowe and Southampton to Scottish ports are also likely to have taken some of these flows from rail.

With a government policy to increase use of rail for these flows, lines have been upgraded over the years; however, not all routes are yet cleared to the necessary standard. It has been speculated that 65-70\% of 40ft containers will be high-cubes by 2023 (Network Rail, 2007),

\footnotetext{
${ }^{3}$ Two different standards of pallet sizes are used. UK pallets (GKN or CHEP brands) measure $1200 \mathrm{~mm} \mathrm{x}$ $1000 \mathrm{~mm}$, whereas European pallets measure $800 \mathrm{~mm} \times 1000 \mathrm{~m}$. See http://www.searates.com/reference/pallets/ for a useful diagram showing how the two pallet types fit into different container sizes. UK pallets are loaded horizontally $(2 \times 1200 \mathrm{~mm})$ and EU pallets vertically $(3 \times 800 \mathrm{~mm})$. A $45 \mathrm{ft}$ pallet-wide container takes the same number of pallets as a road trailer ( 26 UK or 33 Euro), compared to a $45 \mathrm{ft}$ standard width container ( $24 \mathrm{UK}$ or 27 Euro), a 40ft pallet-wide container ( 24 UK or 30 Euro) or a $40 \mathrm{ft}$ standard width container (22 UK or 25 Euro).
} 
thus more detailed data on high-cube movements can contribute towards the planning discussion. In addition, in 2005/6 almost 25\% of deep sea containers went by rail but less than 5\% of short sea containers utilised rail (Network Rail, 2007); by analysing the movement of different container types, this paper can explore some of the reasons behind this result.

Due to reasons of historical development, the loading gauge on the UK rail network is more constrained than in other EU countries (Woodburn, 2008b). This has been enlarged over time to deal with expanding requirements, in particular the increasing height of deep sea containers. While the major parts of the network including the West Coast Main Line (WCML) can now take high-cube deep sea containers on standard wagons (W10 loading gauge), significant portions of the East Coast Maine Line (ECML) are not, which means that an operator must use specialist low wagons to carry high-cube containers (Network Rail, 2007).

Figure 3 shows the current and planned W10 routes on the UK rail network. 


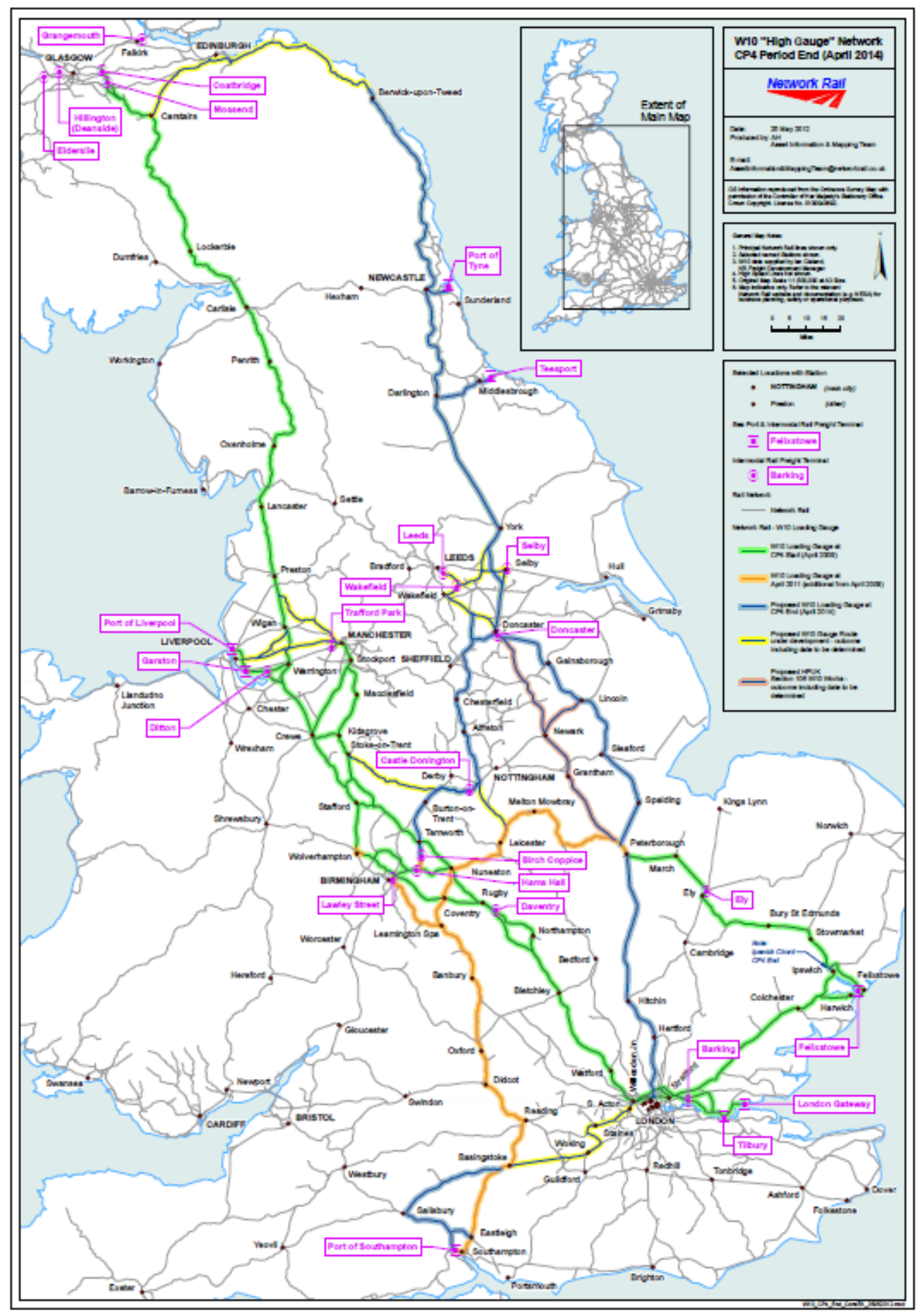

Figure 3. Current and planned W10 routes on the UK rail network.

Note: green and orange $=\mathrm{W} 10$, blue $=$ planned $\mathrm{W} 10$ by April 2014, blue/yellow $=$ proposed $\mathrm{W} 10$ in future.

Source: Network Rail 
The figure shows that the WCML is now fully at W10 standard. The upgrade of Southampton's connection to the WCML to take high-cubes had a noticeably swift result, as DB Schenker secured a deal with CMA CGM to take 25,000 boxes by rail to inland terminals at Birmingham, Manchester Trafford Park and Wakefield (Lloyd's List, 2011). Similarly, Network Rail has finally upgraded the route from Felixstowe to Nuneaton, meaning trains from Felixstowe to the north no longer need to divert through London.

Network Rail is planning to upgrade most of the ECML to W10 by April 2014. The exceptions will be the stretch between North Berwick and Carstairs ${ }^{4}$ and connections from the mainline to the ports of Thamesport, Hull, Grimbsy, Immingham, Bristol, Grangemouth and Greenock. Those ports with existing W10 connections to the WCML (Felixstowe, Southampton, Tilbury and Liverpool) will therefore be better placed for high-cube rail movements. A W10 connection between Teesport and the ECML was planned within this Control Period but has been delayed, perhaps until Control Period 5 (2014-2019).

High-cube containers moving to and from Scotland on standard wagons must use the WCML, to which no east coast port north of Felixstowe has a W10 connection. If Teesport wishes to compete for Scottish cargo (as discussed by Monios \& Wilmsmeier, 2012b; Wilmsmeier \& Monios, 2013), it will be limited by its inability to move high-cube containers on standard wagons.

In order to facilitate transport of high-cube containers on lines below W10 gauge, lower height specialist wagons (e.g. Megafrets) are required. Purchase and maintenance of specialist wagons is typically more expensive, and, as they are $54 \mathrm{ft}$ long, they reduce capacity (compared to the possible container loadings on 60ft wagons used for port flows), thus making them economically undesirable for freight operators (Woodburn, 2008b; Network Rail, 2007). An additional problem is that not many 60ft wagons are optimised for transport of $45 \mathrm{ft}$ containers, providing another difficulty for transportation of short sea containers. WH Davis has recently produced the SL45 (Super Low 45) wagon, which can take high-cubes on W8 routes, and with less wasted length. These could offer solutions on routes that do not take enough traffic for Network Rail to upgrade the loading gauge, such as the north of Scotland. ${ }^{5}$

The other difficulty in loading gauge relates to width. W9 is $2600 \mathrm{~mm}$ wide to take palletwide containers if they are standard height. W10 is higher to accommodate high-cube

\footnotetext{
${ }^{4}$ Since the paper was written, Network Rail has begun consideration of upgrading the Berwick to Carstairs route to W10.

${ }^{5}$ These wagons were used on two short-lived services in 2012: Teesport - Grangemouth operated by DRS and Teesport - Widnes operated by DRS in conjunction with P\&O Ferrymasters to link with ferry sailings bet ween Rotterdam/Zeebrugge and Teesport.
} 
containers but this gauge only offers $2500 \mathrm{~mm}$ width. The larger gauge of W12 (9ft6 high by $2600 \mathrm{~m}$ wide) has since been adopted as the standard for any future work, as it allows carriage of any height or width container on standard wagons (for full details on loading gauge heights and widths see RSSB, 2009a\&b; RSSB, 2013). The wider gauge was developed for palletwide swap bodies and reefers, which are wider than $2500 \mathrm{~mm}$. As noted above, pallet-wide maritime containers are most commonly 8ft2.4in or 2500mm wide (Samskip, 2012; P\&O Ferrymasters, 2014) and can therefore be accommodated within the W10 loading gauge. A minority, however, is wider; the proportion of these containers at $2500 \mathrm{~mm}$ or above passing through UK ports is not currently known (Scott Wilson, 2011), therefore this paper will analyse the new data to answer this question and determine which ports will have potential issues with loading gauge restrictions on their rail connections.

Three research topics can be derived from the preceding discussion, based on the operational dynamics of container type diversification at UK ports. The first issue is that trade imbalances require empty repositioning, resulting in added costs to British shippers. This paper will identify the location and direction of these imbalances and discuss the effects on local shippers. Attempting to balance these flows will require greater knowledge of the individual container types, therefore the second focus of the paper is hinterland accessibility for maritime containers. High-cubes have been predicted to account for almost $70 \%$ of $40 \mathrm{ft}$ containers by 2023, but the discussion above revealed that gauge-cleared routes for highcubes do not connect all ports with their desired hinterlands. This paper will determine the total percentage of high-cubes and which ports dominate these flows. The final topic is the role of European trade, which has been identified as an important speciality at regional ports as part of their strategy to develop and perform a niche role. This speciality can cause an equipment imbalance on road but particularly on rail with wagon/container configuration issues such as $45 \mathrm{ft}$ lengths and larger widths requiring the W12 loading gauge.

\section{The use of data in this analysis}

Due to commercial sensitivity, high quality data on freight movements in the UK are difficult to acquire. Container flows at UK ports are generally discussed as annual throughput figures, but as they are not disaggregated it is not possible to look in detail at some key issues affecting UK trade. This paper will contribute towards filling this gap.

The datasets used have been obtained from the UK Department of Transport (DfT) and Maritime Cargo Processing (MCP) and describe container traffic at UK ports. Few studies on UK container flows have been performed, and these have mostly been based on estimates and 
surveys, without detailed disaggregated data. This paper uses data for 2000 to 2010 (DfT) and 2009 and 2010 (MCP), the latter disaggregated to the level of the individual container movement. The official DfT figures are used for total port throughput, empty movements and port range movements. The MCP dataset contains variables recorded in the port community system, including direction (inbound, outbound), container type, full/empty and weight. The database included 5,935,669 unique records of container movements, which translates into 9,817,643 TEU.

The comparison of the DfT and MCP datasets revealed some discrepancies in total numbers, which probably related to different recording methods and differences in the conversion of movements to TEU. Moreover, the MCP dataset does not provide full coverage of UK ports, or full coverage of all terminals at each port (for detailed comparison of datasets see the appendix). The strength of the MCP data is in its depth, as the large number of individual records allows analysis beyond basic annual figures provided by the DfT. Of the ports included, mapping the dataset against DfT totals gives 84\% (2010) and 85\% (2009) of throughput at these ports. Southampton and Belfast as well as some smaller ports are excluded from the database, meaning that mapping MCP coverage against total UK port throughput gives 64\% (2010) and 65\% (2009). As the MCP data only covers two years the analysis of temporal changes is based on DfT data. Finally, as these data are commercially sensitive, results are presented as aggregates or percentages to protect commercial interests.

\section{Results}

Total UK container throughput in 2010 amounted to 8.2 million TEU, split between 40ft (72\%), 20ft (20\%), greater than 40ft (7\%) and 20-40ft (1\%) containers. 


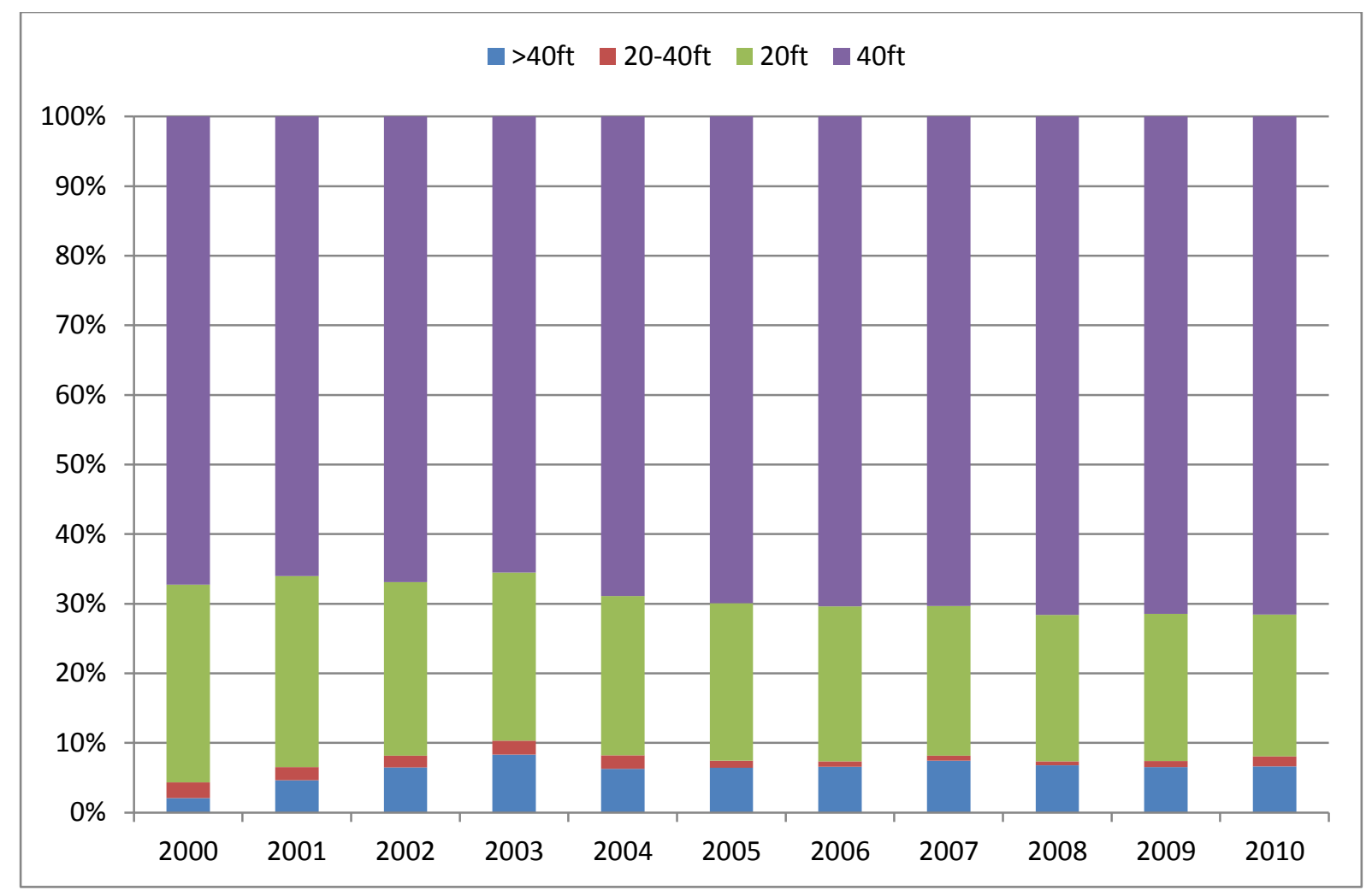

Figure 4. Spread of container lengths per year, 2000-2010

Source: authors, based on DfT, 2011

This spread of container lengths (see Figure 4) has been relatively stable over the past several years, the main change being the increase of $45 \mathrm{ft}$ containers and reduction in $20 \mathrm{ft}$ containers in the early part of the decade. The analysis of the data will be split into one section for each of the three research topics.

\subsection{The effect of trade imbalances}

Empty container movements are a feature of the global maritime system; over the last decade the proportion of empty container handlings in the global total has remained stable at around 20 per cent (Drewry, 2013). Figure 5 shows total inbound and outbound container flows at UK ports since 2000. 


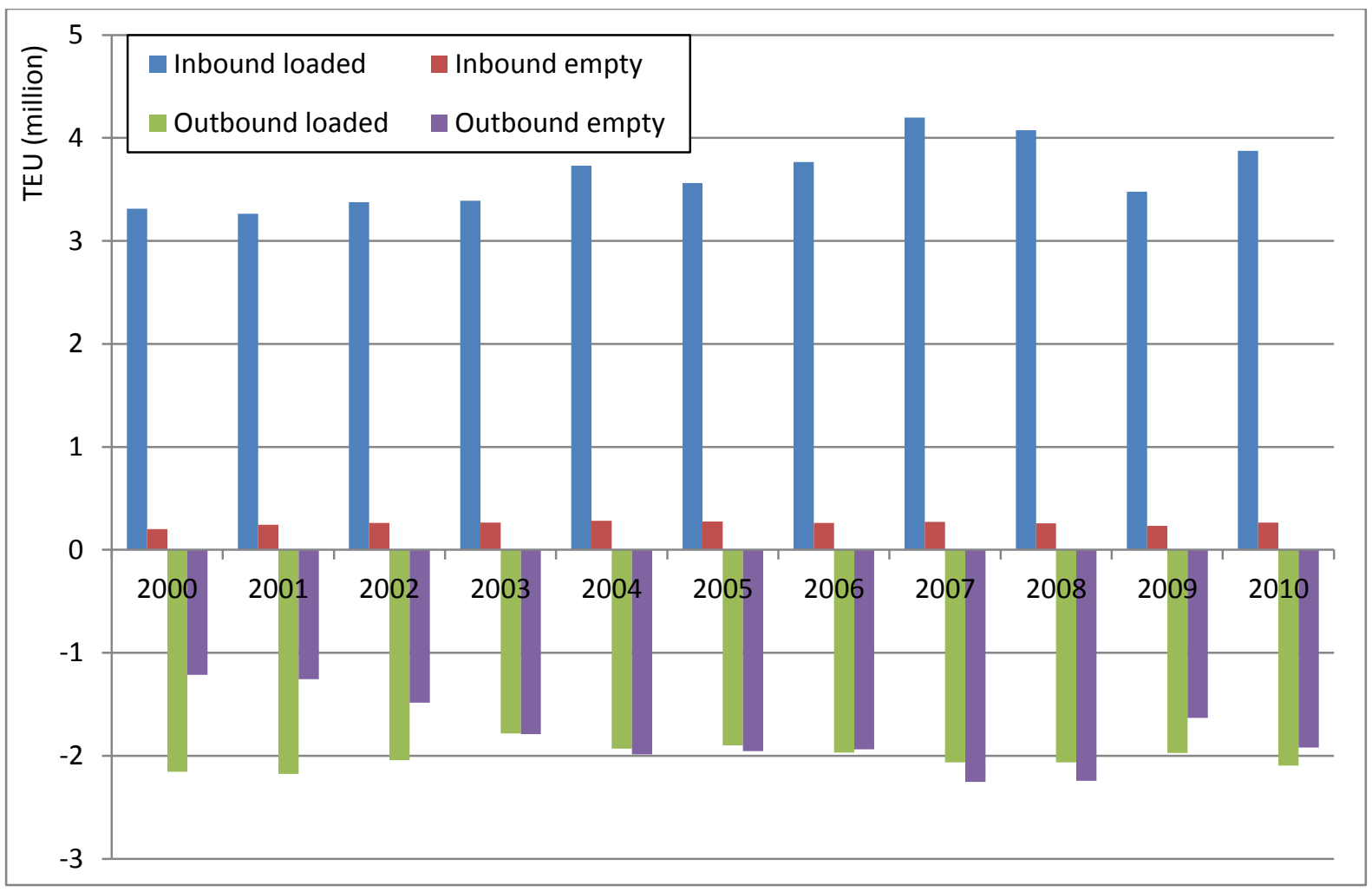

Figure 5. Full and empty movements at all UK ports by direction 2000-2010

Source: authors, based on DfT, 2011

The figure shows that inbound and outbound flows are relatively matched overall. Imports are almost exclusively laden (representing imported goods), while outbound flows are more balanced between full and empty containers (reflecting the large volume of empty containers being repositioned back to the Far East). Thus the UK is shown to be a net importer of goods, in common with many European countries. Moreover, Figure 6 reveals that, while other European countries also handle significant volumes of empty containers, the percentage is highest in the UK (among countries handling more than one million TEU annually). 


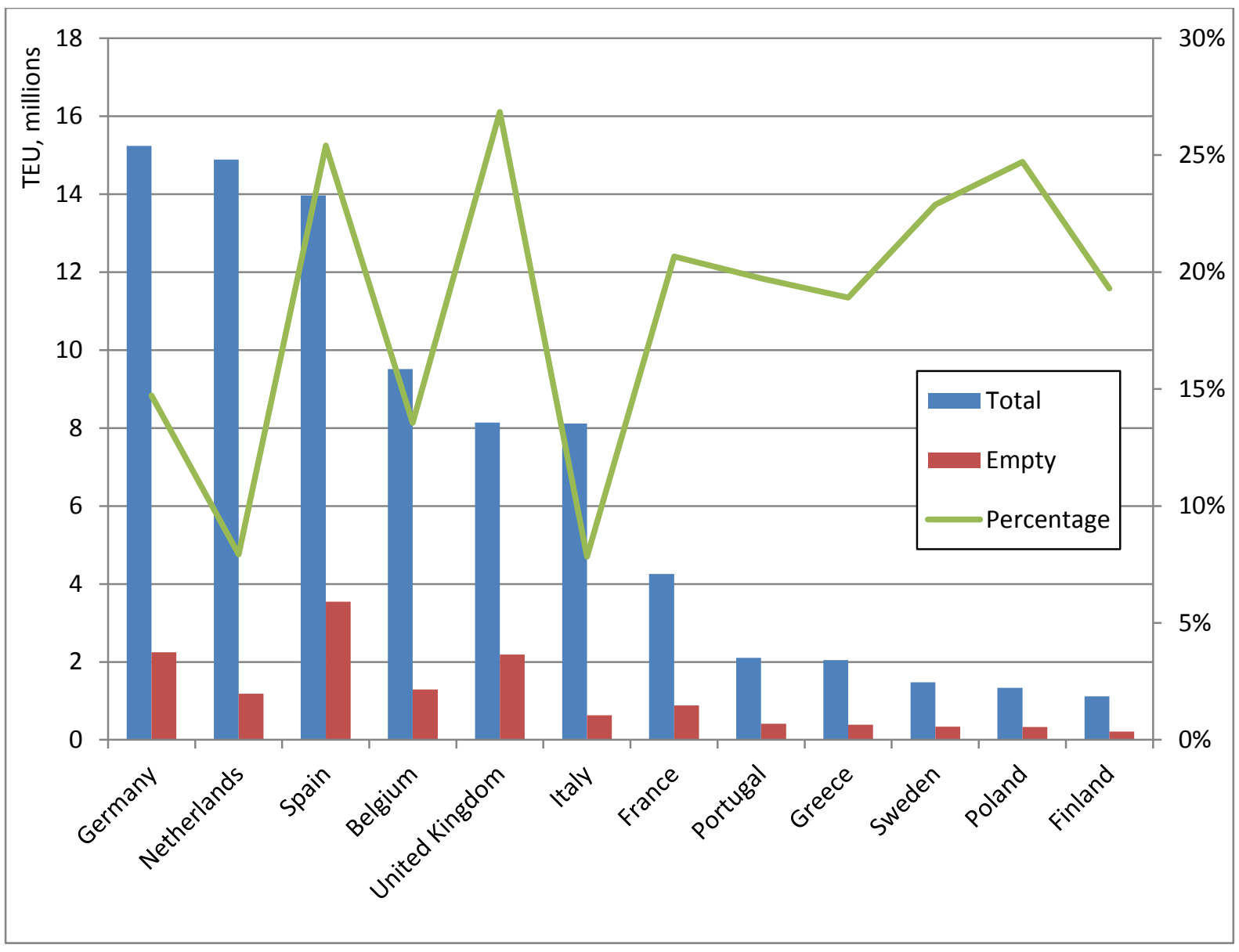

Figure 6. Total and empty container throughput at EU countries, 2011

Note: the figure only shows countries handling more than one million TEU annually Source: authors, based on Eurostat, 2012

Figure 7 shows empty movements in the UK by port and direction in 2010. 


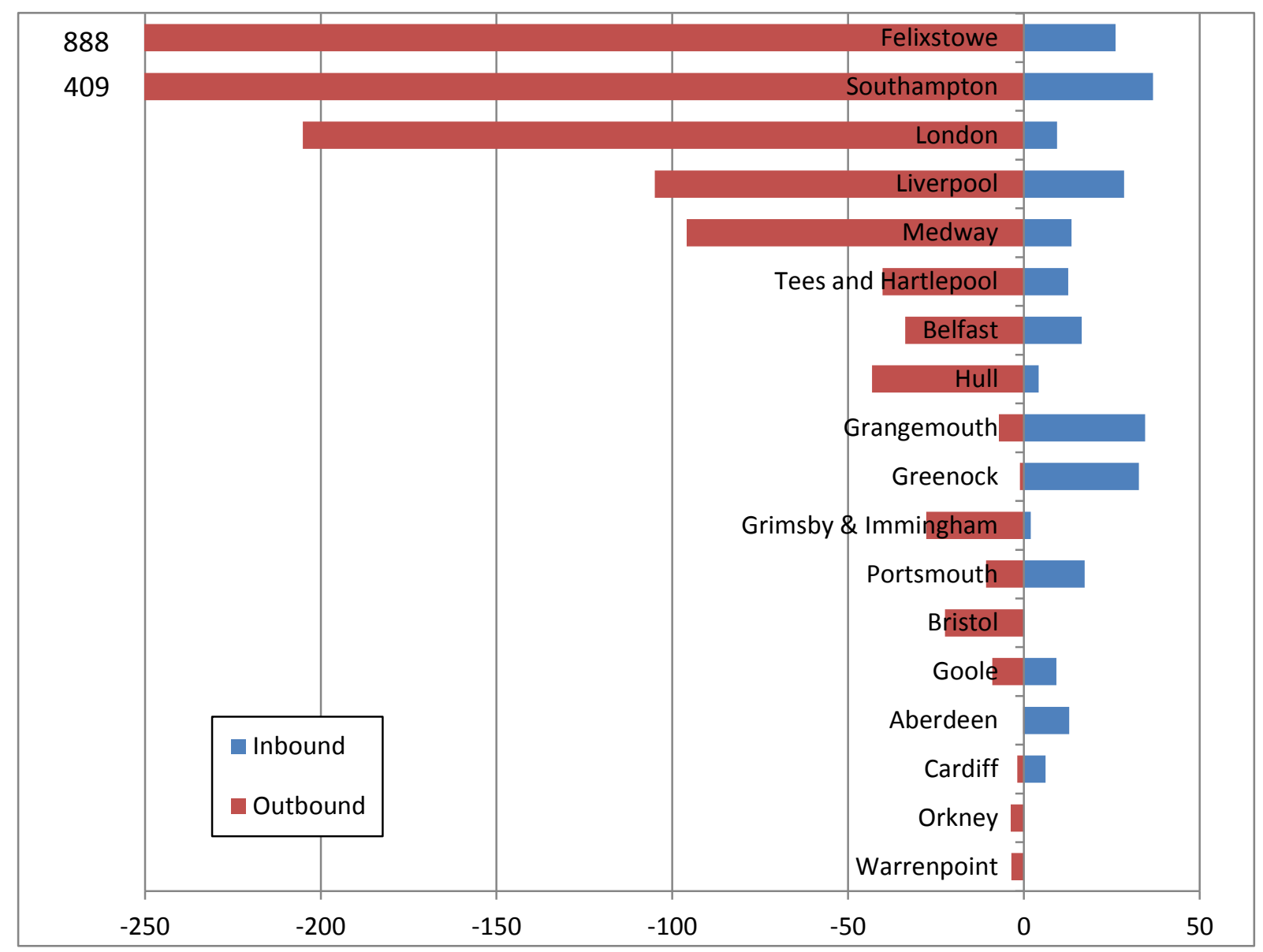

Figure 7. Empty movements 2010, by port and direction (with Felixstowe and Southampton truncated)

Source: authors, based on DfT, 2011

The figure shows that the only ports that import more empties than they export are Grangemouth, Greenock, Portsmouth, Aberdeen, Cardiff and Goole. The Scottish ports have a significant imbalance; other UK ports are generally shipping empties back to the Far East, while Scotland is importing them to fill with export whisky. Monios and Wang (2014) found that between 2006 and 2011 the number of loaded inbound containers at Grangemouth decreased by 42,836 TEU, whereas the number of empties imported rose by 40,315 TEU, almost the same amount. ${ }^{6}$ It could be that Scotland's unitised imports are increasingly arriving overland rather than through its ports, with the result that empty containers must be repositioned. Shipping lines attempt to move empty containers at minimum cost (e.g. using spare capacity on existing services), but the handling and transport costs must still be

\footnotetext{
${ }^{6}$ Before 2006, loaded imports were rising while empty inbound remained stable.
} 
recovered. These costs are borne by the shipper and are therefore a direct cost to Scotland's export industry, although it could be argued that most of these exports are high-value whisky shipments that can absorb the increased cost.

Monios (2012) found that, while most UK retailers are not large enough to manage both primary and secondary distribution, a large retailer like Tesco managing both primary and secondary distribution allows them to match flows to increase the economic viability of a rail service. However, this approach is threatened by the acute container imbalance on the AngloScottish route. Northbound imports to Scotland come mostly as $45 \mathrm{ft}$ pallet-wide road trailers or swap bodies (and now rail containers) as they are retail and other movements from distribution centres in the Midlands. The majority of Scotland's exports leave as $20 \mathrm{ft} / 40 \mathrm{ft}$ maritime containers either through ports or on rail. Thus empty boxes must be repositioned to Scottish ports such as Grangemouth, incurring additional costs to Scottish exporters. This equipment mismatch is also a problem in countries such as the United States where 40ft deep-sea boxes are transloaded into 53ft domestic containers for inland movement.

The figures show the need for empty repositioning through Scottish ports and thus reveal the impact on peripheral areas of the UK due to centralisation of flows in the Midlands. There is an ongoing discussion in the industry at the moment about how to solve this problem on north-south flows in the UK; one proposal involves sharing of boxes and transloading at one end of the chain, although barriers exist to this operation (Monios \& Wang, 2014). To understand this issue further, greater detail is required on the types of containers moving on particular links, as container and wagon mismatches undermine attempts by industry players to match inbound and outbound flows, or primary and secondary distribution. The following sections will consider these issues by examining high-cube containers and European short sea flows.

\subsection{Infrastructure connections and hinterland accessibility}

This section of the paper will compare the hinterland accessibility of UK ports by analysing movements of high-cube containers in comparison to the $\mathrm{W} 10$ rail connections identified in section four. Figure 8 shows the spread of container heights by container length. 


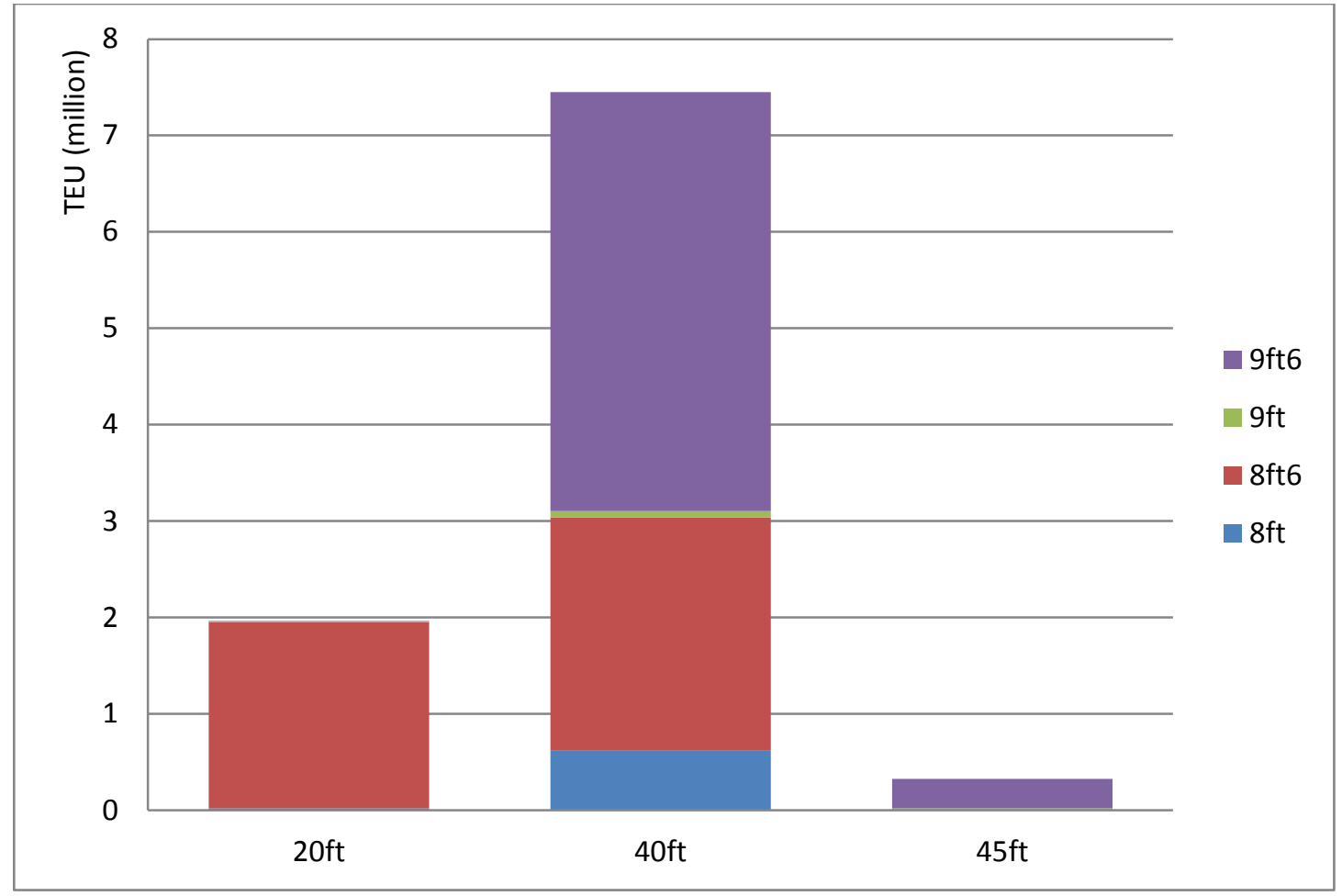

Figure 8. Spread of heights by container length, $2009 \& 2010$

Source: authors, based on dataset

High-cubes (9ft6 height) have been predicted to account for nearly $70 \%$ of $40 \mathrm{ft}$ containers by 2023, and the results show that in 2009 they accounted for 57\% while in 2010 that figure had increased to $59 \%$. Figure 8 reveals that high cubes account for almost the entirety of the $45 \mathrm{ft}$ market, while being almost non-existent for $20 \mathrm{ft}$ containers, which can be explained by the fact that $20 \mathrm{ft}$ containers are used for heavy goods that do not require extra volume.

The next step is to examine high-cube movements by port, because of the loading gauge issue on the UK rail network. 


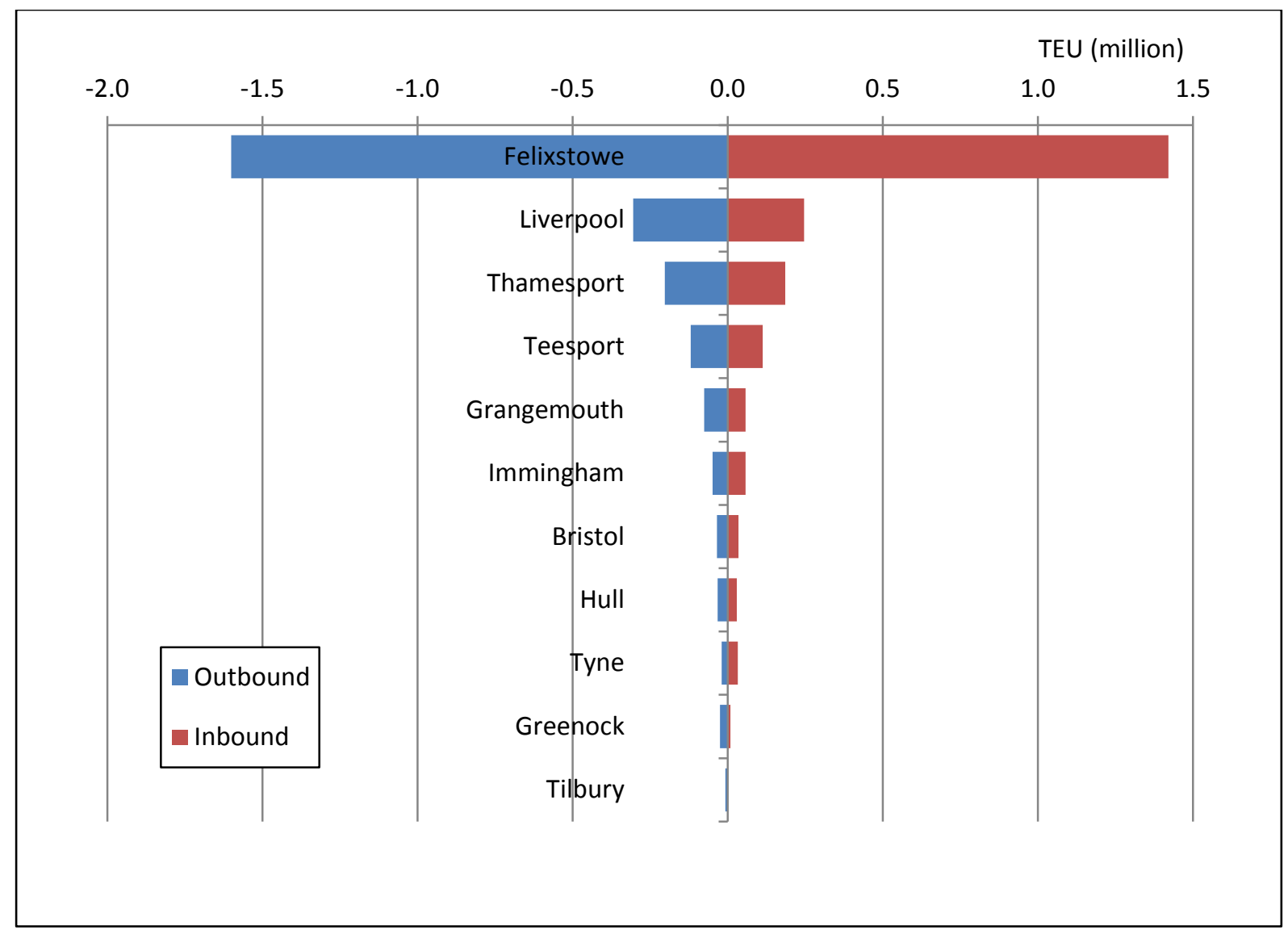

Figure 9. High-cube movements by port $2009 \& 2010$

Source: authors, based on dataset

Figure 9 shows that, while Felixstowe dominates as expected ${ }^{7}$, what is interesting is the other significant high-cube ports, as they do not all have good rail access. The Liverpool line can take high-cubes but Teesport and Thamesport cannot do so unless they use low wagons, adding expense and inconvenience, thus limiting the attractiveness of these routes. The route to Teesport is planned to be upgraded, although it was then delayed, and the connecting route to Scotland is not currently planned for upgrade, which will affect the role this port can play for Scottish cargo, thus limiting its ability to compete for this market, one of its main future goals. The Thamesport route will remain below W10 gauge, and many smaller ports moving high-cubes such as Grangemouth, Immingham, Hull, Bristol and Greenock, do not have W10 connecting routes. It could be that the current network condition has impeded modal shift from road to rail at these ports and will continue to do so until the full network can accommodate W10 container and wagon configurations. A further complication is the larger

\footnotetext{
${ }^{7}$ The low coverage in the dataset on Tilbury and Hull and lack of coverage of Southampton needs to be noted, but these omissions do not affect the results from the other ports.
} 
width of pallet-wide containers used on the intra-European trades. These will be considered in the following section.

\subsection{Specialisations in the short sea European trade}

As discussed in sections three and four, the intra-European short sea trade tends to use $45 \mathrm{ft}$ pallet-wide containers. Consequently, the geographic distribution of these container movements is expected to be concentrated at north-eastern ports, which, as shown in section three, specialise in this market segment. Figure 10 shows movement of $45 \mathrm{ft}$ containers by port in $2010 .^{8}$

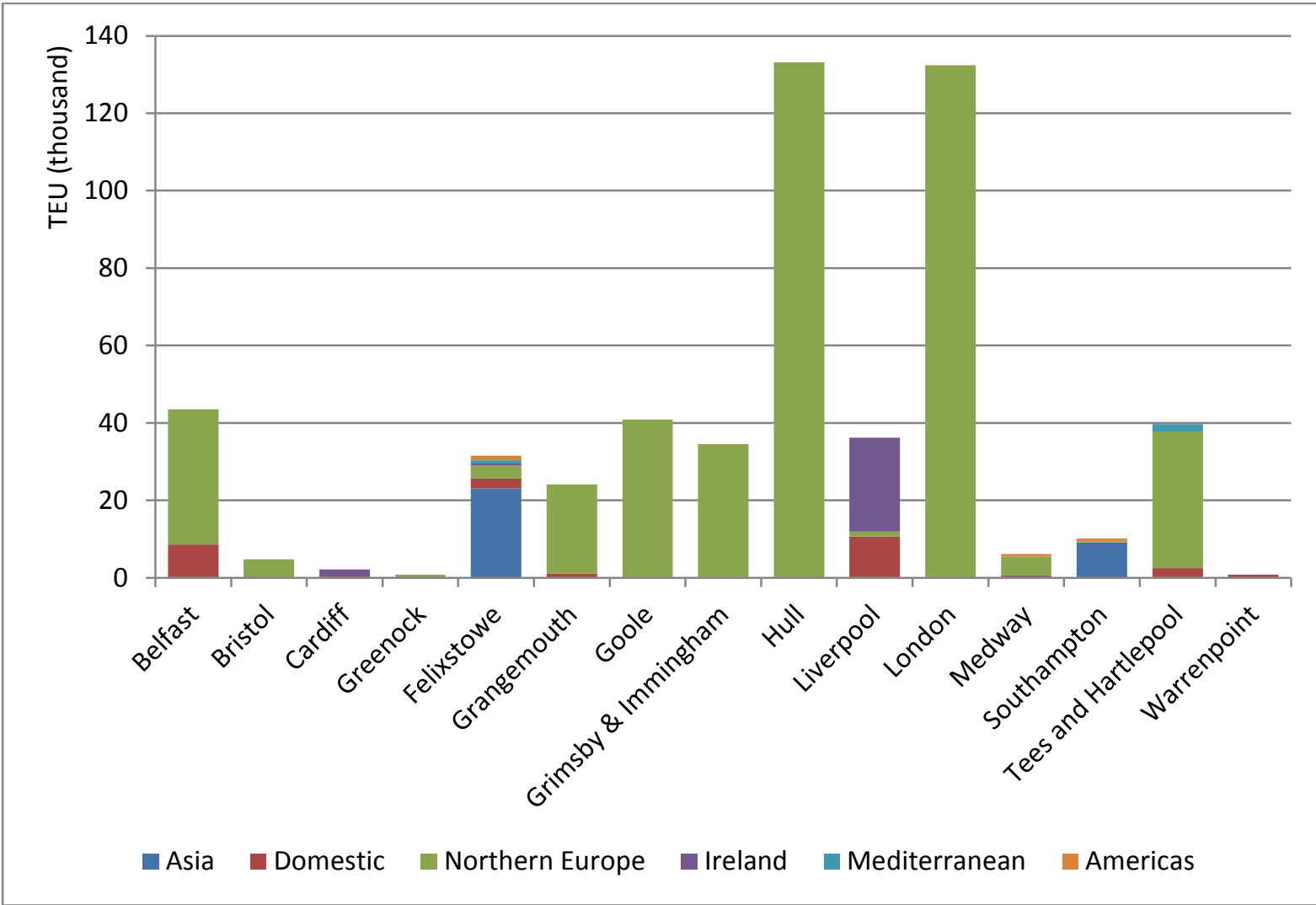

Figure 10. Movements of $45 \mathrm{ft}$ containers by port, 2010

Source: authors, based on DfT, 2011

In 2010, of 540,990 TEU of 45ft containers passing through UK ports, $88 \%$ had European origins/destinations, rising to $93 \%$ when other Mediterranean and domestic O/Ds are added. Hull and London Tilbury were the biggest movers of this container type as well as other regional ports Teesport, Goole, Grimsby and Grangemouth. Due to its location on the west

\footnotetext{
${ }^{8}$ DfT figures show only $>40 \mathrm{ft}$ movements, which are presumed to be almost all if not exclusively $45 \mathrm{ft}$
} containers. 
coast, Liverpool specialises in domestic and Irish container flows. Thus the data confirm the expectation that the majority of $45 \mathrm{ft}$ short sea containers are concentrated at the north-eastern ports identified in Figure 2, as opposed to Felixstowe and Southampton which handle primarily $20 \mathrm{ft} / 40 \mathrm{ft}$ deep-sea containers.

The dataset lists three widths: standard ( $8 \mathrm{ft}$ or $2438 \mathrm{~mm}$ ), $2438-2500 \mathrm{~mm}$ and greater than $2500 \mathrm{~mm}$. High-cubes (9ft6 height) represent $83 \%$ of the larger widths, compared to $46 \%$ of standard widths, demonstrating the expected confluence of high-cube and pallet-wide dimensions. Figure 11 takes the larger two widths together (i.e. everything but standard width) to reveal that the majority of $45 \mathrm{ft}$ and $40 \mathrm{ft}$ high-cube pallet-wide containers move through secondary ports that specialise in the European trade, particularly Teesport. ${ }^{9}$ This reflects the growing importance of these container types in intra-European short sea trade, and if they are to utilise rail, they will require the suitable loading gauge of W10 or W12 as appropriate.

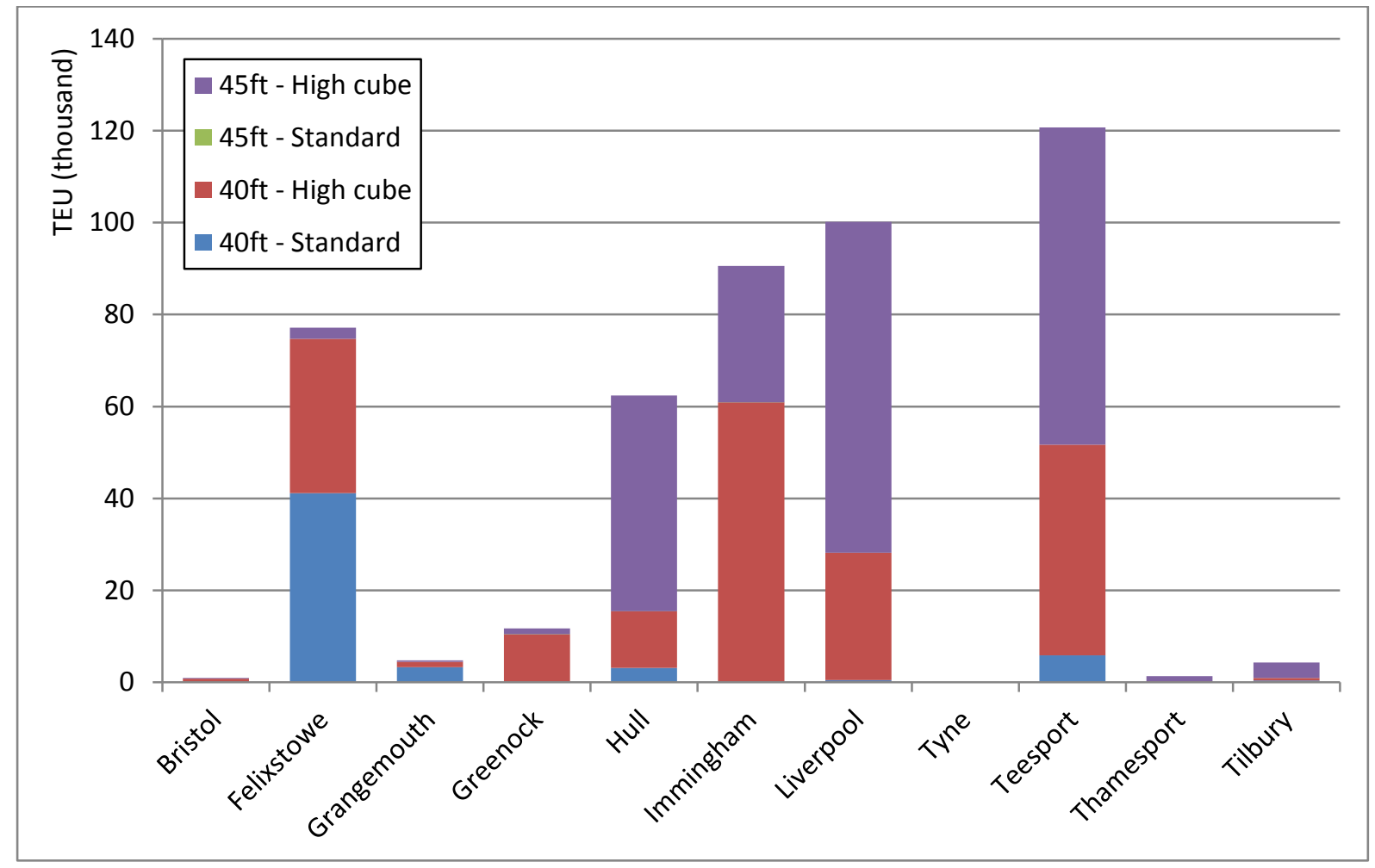

Figure 11. Wider containers, 40ft and 45ft, by port and height, $2009 \& 2010$

Source: authors, based on dataset

\footnotetext{
9 The low coverage in the dataset on Tilbury and Hull and lack of coverage of Southampton needs to be noted, but these omissions do not affect the results from the other ports
} 
As standard pallet-wide containers are $8 \mathrm{ft} 2.4$ inches or $2500 \mathrm{~mm}$ and can fit within the W10 loading gauge, the next step is to determine the proportion of pallet-wide containers that are wider than $2500 \mathrm{~mm}$ and therefore require the wider gauges of W9 (if standard height) or W12 (if high-cube). Looking at total container movements in both 2009 and 2010 given in the dataset, the data show that the vast majority of containers $(94.7 \%)$ are standard width, $5.0 \%$ are between standard and $2500 \mathrm{~mm}$ and only $0.26 \%$ or 25,034 TEU in this sample are over $2500 \mathrm{~mm}$ wide. This means that, while some flows will be constrained by lack of a W12 loading gauge, the majority will be compliant if they have W10. Figure 12 identifies these wider containers, breaks them down by height, and reveals which ports specialise in these flows.

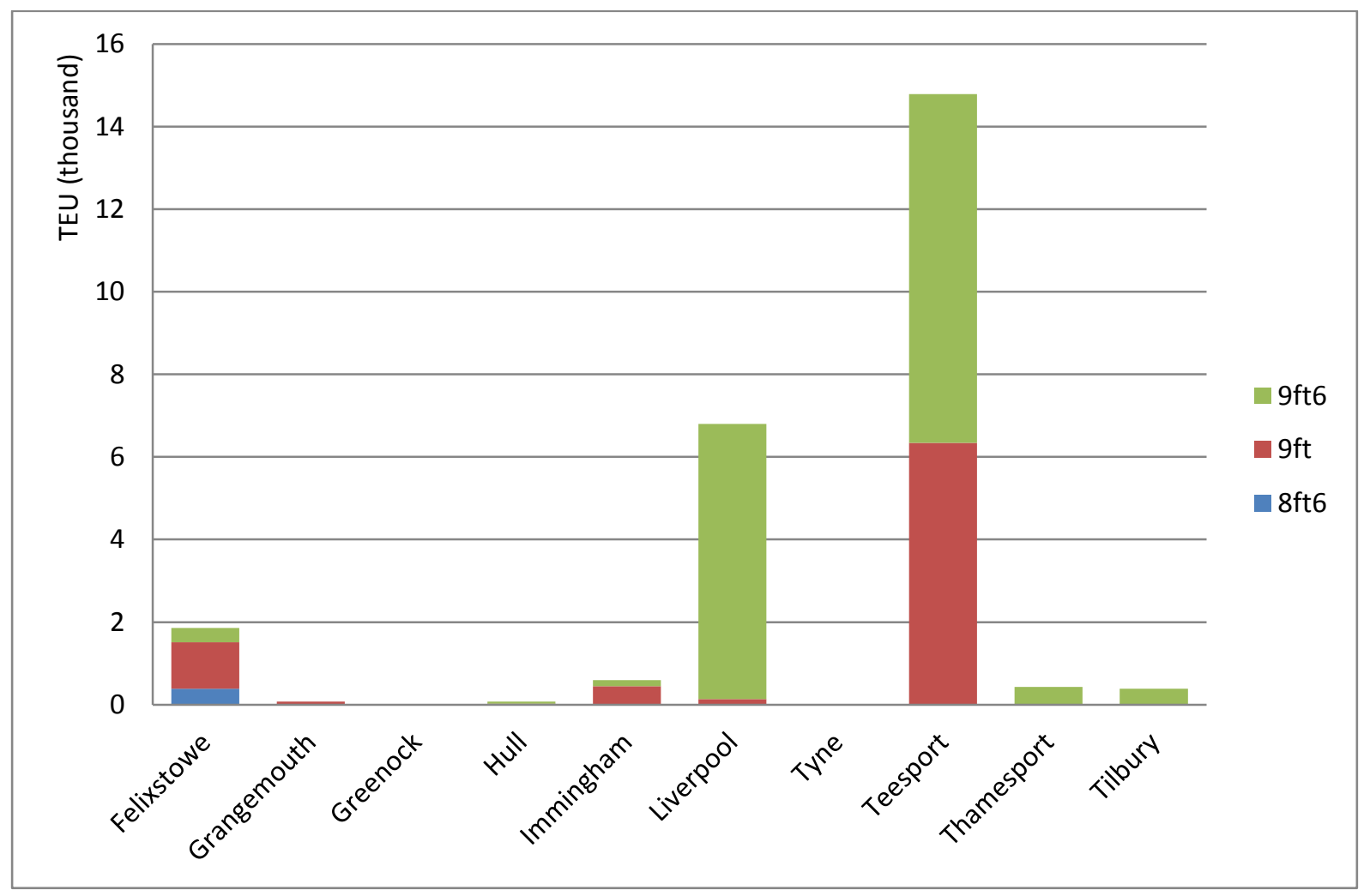

Figure 12. Containers wider than $2500 \mathrm{~mm}$ by port and height, 2009 and 2010 Source: authors, based on dataset

The figure reveals, first, that almost the entirety of these wider containers are also higher than standard height, and thus require the W12 loading gauge. As this is a subset of the previous figure, the same ports are represented, but with a higher focus on Teesport and Liverpool. Again, the dataset is limited to some ports, but it does show that regional ports, unlikely to be upgraded to W12 in the near future, are limited in their ability to move these wider and higher containers. 


\section{Discussion and conclusions}

Major recent port developments in the southeast have ensured that port capacity will be sufficient at a UK level for many years. However, greater flows to regional ports through larger feeder vessels as a knock-on effect of larger ships on mainline routes could reshape inland distribution (e.g. 18,000 TEU vessels only making one or two hub calls in the northern range, which may not be in the UK). Moreover, the high incidence of carrier haulage ${ }^{10}$ in the UK (about 70\%) tends to support rail as a large shipping line bringing thousands of containers on one vessel will book space on the regular Freightliner rail services to move large blocks of containers inland. Using merchant haulage (which is dominant on short sea routes) means that more containers are booked individually and are thus less likely to choose rail. Large retailers such as Tesco are challenging this situation by chartering their own full trains for rail services connecting with short sea routes (see Monios, 2012).

The analysis in this paper has provided some evidence of significant structural differences in container flows across the UK. While empty imbalances at UK level were known, the analysis in this paper has revealed that Scottish ports are disproportionately affected by empty repositioning. The imbalances highlighted in these findings result in additional costs for users, and must be aligned better in order to improve competitiveness. However, imbalances can only be resolved if containers and rail wagons (whether of correct length for container combinations or low height for non-gauge-cleared routes) can be matched on key routes.

One contribution from this study is the importance of high-cubes for regional ports, some of which do not have W10 loading gauge access (either into the port or on northern stretches of the ECML), thus adding inconvenience and expense and proving a barrier to government modal shift targets. Another significant finding is that high-cubes have now eclipsed standard height, accounting for $48 \%$ of total containers in 2010. In particular, high-cube containers dominate the $40 \mathrm{ft}(59 \%)$ and $45 \mathrm{ft}(94 \%)$ markets. The second issue identified is the need for W12 loading gauge to provide the width necessary for the larger high-cube pallet-wide $45 \mathrm{ft}$ short sea containers, although these were shown to be less common than $2500 \mathrm{~mm}$ pallet-wide containers which can be accommodated on the W10 routes. W12 is now the standard for any new work done by Network Rail, but it has not been retrospectively applied across the national network.

\footnotetext{
${ }^{10}$ Carrier haulage means that the inland leg of the journey is managed by the shipping line, as opposed to merchant haulage, which is when the shipper or forwarder arranges the inland movement themselves.
} 
If regional ports want to upgrade and develop their business, their success will be based to a large extent on their ability to serve specific market segments, which relates also to how well these trades fit into the wider geography of container flows. The cost of empty repositioning is a global problem, impacting disproportionately on peripheral regions. The findings in this paper have shown that Scottish ports import a significant volume of empty containers, increasing costs for Scottish shippers. Increased imports through ports could alleviate this problem, but only if such goods are moved in the correct equipment; $45 \mathrm{ft}$ palletwide containers are incompatible with the deep-sea vessels that will transport the cargo once it has been transhipped from a feeder vessel. Planners and policy makers wanting both to support their economies and to encourage use of intermodal transport need to be aware of the difficulties of matching flows and equipment.

Similarly, as regional British ports desire to benefit from an expected growth in feedering to and from continental ports, the economies of scale obtained from larger feeders (for which the expansions at Liverpool and Teesport may make them potential hubs for northern British feeder movements) will be challenged if these movements are a mixture of $20 \mathrm{ft} / 40 \mathrm{ft}$ deep-sea boxes and $45 \mathrm{ft}$ pallet-wide European equipment. While the primary UK container ports Felixstowe and Southampton specialise in $40 \mathrm{ft}$ and $20 \mathrm{ft}$ containers, the biggest movers of $45 \mathrm{ft}$ containers are Hull and London Tilbury, as well as other regional ports Teesport, Goole, Liverpool, Grimsby and Grangemouth. In order to serve the centralised British logistics market as well as Scotland, these container flows will need to be balanced in both directions to achieve the required economic viability on these routes. This is particularly important for the use of rail, which requires complementarities of container and wagon configurations. Matching 45ft pallet-wide containers with 40ft deep-sea boxes will lower the efficiency of wagon utilisation, and lack of high-cube access across the network (particularly the ECML) will also hinder this aim. Moreover, a lack of W12 paths to accommodate the extra width of some containers provides another limitation for ports seeking rail access for these flows.

One focus of this paper was on rail connections, related to the government priority to encourage use of rail. A clear finding is the importance of high-cube containers at ports without a W10 rail connection, or without a full ECML W10 route, meaning that rail users will incur additional expense if shipping through these ports because they will need to use low wagons, compared with the larger ports with W10 cleared routes and WCML access. Network Rail is gradually addressing the need for W10 routes, but provision of W12 gauge for the $>2500 \mathrm{~mm}$ pallet-wide containers, swap bodies and reefers is further in the future. This 
will affect not only British shippers in the intra-European trade but continental shippers and forwarders as well.

Even if users of these ports do not use rail, the different container requirements of importers and exporters will undermine attempts to attract shippers to use these ports rather than the dominant south-eastern ports whose large concentration of container flows limit these operational problems. This is of particular relevance considering the goal of many secondary British ports is to anchor tenants on port land through a port-centric logistics strategy. Availability of suitable equipment will be essential, and if logistics costs are increased because road hauliers distributing from these locations incur additional empty running due to container repositioning, these locations will be less attractive and will be unable to overcome the strong centralisation tendencies in the UK logistics network.

Regional UK ports are pursuing significant port expansions to take advantage of changing trends in container flows, seeking to reposition themselves within an emerging feeder market that could reduce their peripherality that has been embedded by the current concentrated UK port and infrastructure system. Proactive strategies such as those by Liverpool and Teesport seem to be challenging the path dependence of container flows, although the ability of Teesport to challenge for northern markets remains constrained by its lack of suitable connecting rail infrastructure, as well as availability of correct container types for regional shippers. This paper has identified challenges to these developments, relating to rail infrastructure provision, the structure of trade and equipment imbalances. The paper thus raises questions about transport policy and both public and private sector responses to a changing UK port geography.

When analysing a port development project, private sector port developers must remain aware of the effects not only of path dependence (suggesting the continued dominance of the current major ports) but also the contingency of port development upon securing public planning approval. Conversely, public sector planners must recognise the importance of attracting private finance into the port sector. Development projects at smaller ports need a sound business case that itself relies on detailed market knowledge of the logistics requirements of potential port customers.

Peripheral ports in Europe face similar issues, as they attempt to position themselves as feeder satellites within the orbit of large hub ports while also remaining responsive to the needs of local and regional shippers. While other countries do not have the same loading gauge restrictions as the $\mathrm{UK}$, issues relating to empty repositioning (due to a predominantly importing economy) and the management of wagon and container types (due to 20/40ft deep 
sea and $45 \mathrm{ft}$ short sea boxes) are faced across Europe. Findings related to both of these issues in the UK suggest that European countries will experience the same challenges to rail inefficiency, for two reasons. First, because empty movements are unproductive, whether the cost is borne by the shipping line or the shipper, and second, because operating regular block trains of fixed wagon sets may be undermined by unused wagons due to the variation in container types awaiting transport. Such regional ports require a detailed understanding of the equipment requirements of their customer base if they are to maintain their current business and attract new clients, particularly if they want to anchor them in the ports through the provision of storage and distribution facilities. The danger is that, by serving a mixed customer base, inefficiencies arise that reduce the scale economies crucial to modern port operation.

\section{Acknowledgements}

Thanks are due to the two anonymous reviewers whose detailed comments enabled us to improve the paper substantially. Research for this paper was funded by the EU Interreg IVB North Sea Region Dryport and GreCor projects.

\section{Appendix. Cleaning the data from the new dataset}

Table 1 shows the availability of port flows in the dataset, ranked in order of 2010 throughput from the DfT figures.

Table 1. List of UK ports by 2010 container throughput and dataset coverage

\begin{tabular}{|l|l|c|c|c|c|}
\hline $\begin{array}{l}\text { Rank } \\
2010 \\
(\text { DfT })\end{array}$ & Port & $\begin{array}{c}2010 \\
\text { throughput } \\
\text { TEU (DfT) }\end{array}$ & $\begin{array}{c}\text { Coverage in } \\
\text { dataset }\end{array}$ & $\begin{array}{c}2009 \\
\text { throughput } \\
\text { TEU (DfT) }\end{array}$ & $\begin{array}{c}\text { Coverage in } \\
\text { dataset }\end{array}$ \\
\hline 1 & Felixstowe & $3,415,299$ & $106 \%$ & $3,020,879$ & $106 \%$ \\
\hline 2 & Southampton & $1,563,573$ & N/A & $1,381,419$ & N/A \\
\hline 3 & London (Tilbury) & 732,711 & $7 \%$ & 646,893 & $8 \%$ \\
\hline 4 & Liverpool & 661,802 & $87 \%$ & 588,053 & $86 \%$ \\
\hline 5 & $\begin{array}{l}\text { Thamesport } \\
\text { (Medway) }\end{array}$ & 440,316 & $83 \%$ & 422,814 & $100 \%$ \\
\hline 6 & Teesport & 252,098 & $95 \%$ & 178,410 & $96 \%$ \\
\hline 7 & Grangemouth & 216,747 & $71 \%$ & 230,676 & $71 \%$ \\
\hline
\end{tabular}




\begin{tabular}{|l|l|c|c|c|c|}
\hline 8 & Belfast & 214,467 & N/A & 212,622 & N/A \\
\hline 9 & Hull & 202,933 & $21 \%$ & 182,209 & $14 \%$ \\
\hline 10 & $\begin{array}{l}\text { Grimsby } \\
\text { Immingham }\end{array}$ & 109,825 & $97 \%$ & 133,340 & $95 \%$ \\
\hline 11 & Greenock (Clyde) & 82,083 & $45 \%$ & 71,550 & $29 \%$ \\
\hline 12 & Goole & 70,354 & N/A & 55,911 & N/A \\
\hline 13 & Bristol-Avonmouth & 69,271 & $87 \%$ & 71,666 & $86 \%$ \\
\hline 14 & Tyne-Newcastle & 57,219 & $71 \%$ & 37,201 & $70 \%$ \\
\hline 15 & Portsmouth & 52,018 & N/A & 56,828 & N/A \\
\hline 16 & Aberdeen & 33,514 & N/A & 27,546 & N/A \\
\hline 17 & Cardiff & 19,992 & N/A & 15,469 & N/A \\
\hline 18 & Orkney & 12,246 & N/A & 0 & N/A \\
\hline 19 & Warrenpoint & 8,420 & N/A & 17,464 & N/A \\
\hline 20 & Poole & 3,445 & N/A & 0 & N/A \\
\hline 21 & Harwich & 2,435 & $120 \%$ & 2,391 & $66 \%$ \\
\hline 22 & Ipswich & 1,278 & $67 \%$ & 445 & $57 \%$ \\
\hline
\end{tabular}

It can be seen that some ports are missing from the dataset. Using DfT figures, this means a loss of $24 \%$ of throughput. Second, not all ports in the database have full coverage, and in three cases more than $100 \%$ coverage is observed, indicating some unreliable data. However given the size of the database, these discrepancies are not considered serious, probably being related to different recording methods and differences in the conversion of movements to TEU. Across the two years, MCP coverage of the available ports is $85 \%$, whereas MCP coverage of total ports (i.e. the ports in the database and those missing) is $65 \%$.

TEU figures were calculated according to the first digit of the container type as given by ISO 6346 (1995 \& 1984). ISO codes, both current (1995) and previous (1984) were used to analyse container type structures as they provide length, height and width of the containers. According to ISO 6346, agreed in 1995, the first figure in the four digit container number records the length, the second figure records the height and width (a different figure for different height/width combinations, e.g. 5 is high-cube while $\mathrm{E}$ or $\mathrm{N}$ is high-cube with larger width), the third figure denotes the type (e.g. G for general container, R for reefer), and the fourth denotes the subset of that category (e.g. G0 is standard, G1 has vents). 


\section{References}

Arnold, P., Peeters, D., Thomas, I. (2004). Modelling a rail/road intermodal transportation system. Transportation Research Part E. 40 (3): 255-270.

Asteris, M., \& Collins, A. (2010). UK container port investment and competition. Transport Reviews, 30(2), 163-178.

Ballis, A., Golias, J. (2002). Comparative evaluation of existing and innovative rail-road freight transport terminals. Transportation Research Part A. 36 (7): 593-611.

Bärthel, F., Woxenius, Y. (2004). Developing intermodal transport for small flows over short distances. Transportation Planning \& Technology. 27 (5): 403-424.

Bergqvist, R. (2008). Realising logistics opportunities in a public-private collaborative setting: the story of Skaraborg. Transport Reviews, 28 (2): 219-237.

Bouley, C. (2012). Manifesto for the 45' palletwide container: a green container for Europe. http://issuu.com/cjbouley/docs/manifesto_for_the_45_pallet_wide_container Accessed 16th March 2012.

Cahoon, S., Pateman, H., Chen, S-L. (2012). Regional port authorities: leading players in innovation networks? Journal of Transport Geography. 27: 66-75.

Caris, A., Macharis, C., Janssens, G. K. (2008). Planning problems in intermodal freight transport: accomplishments and prospects. Transportation Planning \& Technology. 31 (3): 277-302.

Cullinane, K.P.B., Khanna, M. (1999). Economies of Scale in Large Container Ships. Journal of Transport Economics and Policy, 33(2), 185-208.

DETR. (1998). A New Deal for Transport: Better for Everyone. London: Department of the Environment, Transport and the Regions.

De Langen, P. W. (2008). Ensuring hinterland access: the role of port authorities. JTRC OECD/ITF Discussion Paper 2008-11.

De Langen, P. W., Sharypova, K. (2013). Intermodal connectivity as a port performance indicator. Research in Transportation Business \& Management. In press.

Department for Transport. (2011). DfT Port Statistics. London: DfT.

Drewry Shipping Consultants, 2013. Container market - 2012/13. Annual review and forecast. London: Drewry publishing.

Ducruet, C., Van der Horst, M. (2009). Transport integration at European ports: measuring the role and position of intermediaries. EJTIR. 9 (2): 121-142. 
Eng-Larsson, F., Kohn, C. (2012). Modal shift for greener logistics - the shipper's perspective. International Journal of Physical Distribution and Logistics Management. 42 (1): 36-59.

European Commission. (2001). European Transport Policy for 2010: Time to Decide. Luxembourg: European Commission.

Eurostat, 2012. Country level - Volume (in TEUs) of containers handled in main ports, by loading status. Available at: http://epp.eurostat.ec.europa.eu/portal/page/portal/statistics/search_database Accessed 29th May 2013.

Flämig, H., Hesse, M. (2011). Placing dryports. Port regionalization as a planning challenge the case of Hamburg, Germany, and the Süderelbe. Research in Transportation Economics. 33 (1): 42-50.

Hesse, M., Rodrigue, J-P. (2004). The transport geography of logistics and freight distribution. Journal of Transport Geography. 12 (3): 171-184.

Hoare, A. G. (1986). British ports and their export hinterlands: a rapidly changing geography. Geografiska Annaler, 68B(1), 29-40.

Iannone, F. (2012). A model optimizing the port-hinterland logistics of containers: The case of the Campania region in Southern Italy. Maritime Economics \& Logistics. 14 (1): 3372.

Janic, M. (2007). Modelling the full costs of an intermodal and road freight transport network. Transportation Research Part D: Transport and Environment. 12 (1): 33-44.

Kim, N. S., Wee, B. V. (2011). The relative importance of factors that influence the breakeven distance of intermodal freight transport systems. Journal of Transport Geography. 19 (4): 859-875.

Kreutzberger. E. D. (2008). Distance and time in intermodal goods transport networks in Europe: a generic approach. Transportation Research Part A: Policy \& Practice. 42 (7): 973-993.

Lloyd's List. (2011). CMA CGM signs two-year rail deal with DB Schenker at Southampton. http://www.lloydslist.com/1//sector/ports-and-logistics/article368643.ece $A c c e s s e d 16^{\text {th }}$ March 2012.

Mangan, J., Lalwani, C., \& Fynes, B. (2008). Port-centric logistics. The International Journal of Logistics Management, 19(1), 29-41.

Monios, J. (2012). Retail logistics in the UK. Paper presented at the International Conference on Logistics \& Sustainable Transport, Celje, Slovenia, June 2012. 
Monios, J., Wang, Y. (2014). Regional stakeholder solutions to empty container repositioning costs in peripheral regions. Paper presented at the annual conference of the International Association of Maritime Economists (IAME). Norfolk, USA, July 2014.

Monios, J., Wilmsmeier, G. (2012a). Giving a direction to port regionalisation. Transportation Research Part A: Policy \& Practice. 46 (10): 1551-1561.

Monios, J., Wilmsmeier, G. (2012b). Port-centric logistics, dry ports and offshore logistics hubs: strategies to overcome double peripherality? Maritime Policy and Management, 39(2), 207-226.

Monios, J., Wilmsmeier, G. (2013). The role of intermodal transport in port regionalisation. Transport Policy. 30: 161-172.

Network Rail. (2007). Freight Route Utilisation Strategy. London: Network Rail.

Ng, K. Y. A., Cetin, I. B. (2012). Locational characteristics of dry ports in developing economies: some lessons from Northern India. Regional Studies. 46 (6): 757-773.

Notteboom, T. E. (2010). Concentration and the formation of multi-port gateway regions in the European container port system: an update. Journal of Transport Geography, 18(4), $567-583$.

Notteboom, T. E., Rodrigue, J-P. (2005). Port regionalization: towards a new phase in port development. Maritime Policy \& Management. 32 (3): 297-313.

Notteboom, T. E., Rodrigue, J-P. (2009). Inland terminals within North American \& European Supply Chains, in: Transport and Communications Bulletin for Asia and the Pacific No. 78: Development of Dry Ports. New York: UNESCAP.

Overman, H. G., \& Winters, L. A. (2005). The port geography of UK international trade. Environment \& Planning A, 37(10), 1751-1768.

P\&O Ferrymasters. (2014). Fleet specification. Available at:

http://www.poferrymasters.com/about-us/our-fleet/fleet-specification Accessed 14th March 2014.

Panayides, P. M. (2002). Economic organisation of intermodal transport. Transport Reviews. 22 (4): 401-414.

Pettit, S. J., \& Beresford, A. K. C. (2008). An assessment of long-term United Kingdom port performance: a regional perspective. Maritime Economics \& Logistics, 10(1), 53-74.

Pettit, S. J., \& Beresford, A. K. C. (2009). Port development: from gateways to logistics hubs. Maritime Policy \& Management, 36(3), 253-267.

Rail Safety and Standards Board. (2009a). Guidance on gauging. GE/GN8573. Issue 3. October 2009. Available at: 
http://www.rgsonline.co.uk/Railway_Group_Standards/Infrastructure/Guidance\%20Notes /GEGN8573\%20Iss\%203.pdf Accessed 14 ${ }^{\text {th }}$ March 2014.

Rail Safety and Standards Board. (2009b). Requirements for the application of standard vehicle gauges. GE/RT8073. Issue 2. October 2009. Available at: http://www.rgsonline.co.uk/Railway_Group_Standards/Infrastructure/Railway\%20Group \%20Standards/GERT8073\%20Iss\%202.pdf Accessed 14 ${ }^{\text {th }}$ March 2014.

Rail Safety and Standards Board. (2013). Working manual for rail staff - freight operations. Appendix J - Intermodal traffic. GO/RT3056/J. Issue 2. June 2013. Available at: http://www.rgsonline.co.uk/Railway_Group_Standards/Traffic\%20Operation\%20and\%2 0Management/Railway\%20Group\%20Standards/GORT3056-J\%20Iss\%202.pdf Accessed 14 ${ }^{\text {th }}$ March 2014.

Rodrigue, J-P., Notteboom, T. (2010). Comparative North American and European gateway logistics: the regionalism of freight distribution. Journal of Transport Geography. 18 (4): 497-507.

Rodrigue, J-P., Debrie, J., Fremont, A., Gouvernal, E. (2010). Functions and actors of inland ports: European and North American dynamics. Journal of Transport Geography. 18 (4): 519-529.

Roso, V., Woxenius, J., Lumsden, K. (2009). The dry port concept: connecting container seaports with the hinterland. Journal of Transport Geography. 17 (5): 338-345.

Runhaar, H., van der Heijden, R. (2005). Public policy intervention in freight transport costs: effects on printed media logistics in the Netherlands. Transport Policy. 12 (1): 35-46.

Samskip. (2012). Equipment: details and internal dimensions. Available at: http://www.evo.nl/site/samskipcontainervervoer/\$FILE/276405_NM37503_factsheet_HQ.pdf Accessed 14th March 2014.

Scott Wilson. (2012). Parkside strategic rail freight interchange evidence base background paper - update January 2011. Available at: http://www.sthelens.gov.uk/media/159291/tp42c.pdf Accessed 14th March 2014.

Slack, B., Vogt, A. (2007). Challenges confronting new traction providers of rail freight in Germany. Transport Policy. 14 (5): 399-409.

Van den Berg, R., De Langen, P. W., Costa, C. R. (2012). The role of port authorities in new intermodal service development: the case of Barcelona Port Authority. Research in Transportation Business \& Management. In press. 
Van der Horst, M. R., De Langen, P. W. (2008). Coordination in hinterland transport-chains: a major challenge for the seaport community. Maritime Economics \& Logistics. 10 (1-2): 108-129.

Van Schijndel, W. J., Dinwoodie, J. (2000). Congestion and multimodal transport: a survey of cargo transport operators in the Netherlands. Transport Policy. 7 (4): 231-241.

Wilmsmeier, G., \& Monios, J. (2013). Counterbalancing peripherality and concentration: an analysis of the UK container port system. Maritime Policy \& Management. 40 (2): 116132.

Woodburn, A. (2003). A logistical perspective on the potential for modal shift of freight from road to rail in Great Britain. International Journal of Transport Management. 1 (4): 237245.

Woodburn, A. (2007). The role for rail in port-based container freight flows in Britain. Maritime Policy \& Management, 34(4), 311-330.

Woodburn, A. (2008a). Intermodal rail freight in Britain: a terminal problem? Planning, Practice \& Research, 23(3), 441-460.

Woodburn, A. (2008b). The challenge of high-cube ISO containers for British rail freight operations. In: Logistics Research Network Annual Conference 2008: Supply Chain Innovations: people, practice and performance, 10 - 12 Sep 2008, University of Liverpool, UK. (Unpublished)

Woodburn, A. (2011). An investigation of container train service provision and load factors in Great Britain. European Journal of Transport and Infrastructure Research, 11 (2): 147-165.

Woxenius, J., Bergqvist, R. (2011). Comparing maritime containers and semi-trailers in the context of hinterland transport by rail. Journal of Transport Geography. 19 (4): 680-688. 